\author{
Oliver Koch \\ ORCID: 0000-0003-1748-8025
}

University of Konstanz

https://doi.org/10.19195/1733-5779.34.11

\title{
How the German Pension System can benefit from insights of behavioral economics
}

JEL Classification: D90, E70, G40, H55, J10, J32

Keywords: demographic crisis, pension system, behavioral economics, nudge

Słowa kluczowe: kryzys demograficzny, system emerytalny, ekonomia behawioralna, nudging, koncepcja reformy emerytalnej

\begin{abstract}
Due to the demographic change that has been going on for several decades, the pension system in Germany is being heavily burdened. The German pension system can be described as a three-pillar system that includes not only the compulsory statutory pension insurance, but also the company pension schemes and the private pension schemes. However, the statutory pension insurance is particularly affected by the demographic crisis. The resulting declining birth rates and the rising life expectancy caused an unfavorable ratio between contributors and recipients of this system. Several pension reforms have already been introduced in Germany in order to manage this crisis, but the expected results did not occur. This article is therefore concerned with the findings of behavioral economics and what solutions it gives for this problem. In addition, a reform concept for Germany with behavioral economic elements is presented - "Deutschlandrente".
\end{abstract}

\section{Jak niemiecki system emerytalny może skorzystać dzięki wiedzy ekonomii behawioralnej}

Abstrakt: Celem artykułu jest zbadanie, w jaki sposób niemiecki system emerytalny może skorzystać ze spostrzeżeń z zakresu ekonomii behawioralnej w celu zainicjowania nowych skutecznych reform emerytalnych w kontekście problemów związanych z zachodzącymi zmianami demograficznymi. W tekście przedstawiono też behawioralne środki ekonomiczne dotyczące sposobów zwiększenia rozpowszechnienia dodatkowych planów emerytalnych w celu przezwyciężenia tego problemu. Dodatkowo opisano koncepcję reformy emerytalnej niemieckiego systemu emerytalnego — tak zwanego Deutschlandrente. 


\section{Introduction}

The demographic change that is ongoing since the early 1970s has a considerable influence on the German pension system and causes a lot of problems for it. It is a problem that connects all countries across the European Union. This demographic change is influenced by three factors: fertility, mortality and migration. In the coming decades, the German population will change dramatically. This dramatic change does not only refer to the sheer number of people living in Germany today and in the future, but also and especially to age structure.

In order to better manage the problems that the demographic crisis brings to the German pension system, the field of behavioral economics offers solutions that already have been put into practice in many other countries. A behavioral economic policy tool that has attracted a lot of attention and is already the basis for pension reforms in many countries is the principle of nudging. Nudging can be described with a gentle pressure, with which the state helps people to find the right direction, but at the same time leaves them the option to change their minds if they want to.

As further pension reforms are urgently needed in Germany, this article investigates how the German pension system can benefit from insights of behavioral economics in order to initiate new effective pension reforms.

\section{Demographic crisis and the German Pension System}

The demographic change in Germany is characterized by the fact that since the early 1970 s the fertility rate is lower than the mortality rate, which is why the population would decline without immigration. Another characteristic is the higher life expectancy of the population, which, when the fertility rate declines, leads to a larger proportion of the older population compared to the share of the younger population. The interaction of these effects in Germany will cause the population to drop steadily from around 80.2 million today to around 73.1 million in $2060 .{ }^{1}$

The total fertility rate is thus a value of great statistical importance. It indicates the average number of children a woman would have during her life if, for the specific moment of time, the prevailing age-specific fertility conditions for her 15 th to 49 th year of age were valid. ${ }^{2}$ This value has stagnated in Germany at a level of 1.4 children per woman for several decades and this value is assumed to be approximately constant in the future. ${ }^{3}$ Considering that a fertility rate of around 2.1 would be needed in order to keep the population constant or to replace it completely, the actual fertility rate of 1.4 is far too low.

${ }^{1}$ Statistisches Bundesamt, Bevölkerung Deutschlands bis 2060. 13. koordinierte Bevölkerungsvorausberechnung, Wiesbaden 2015, p. 6.

2 C. Haub, Dynamik der Weltbevölkerung, Stuttgart 2002, p. 12.

3 Statistisches Bundesamt, op. cit., p. 27. 
The problems with mortality can be best expressed by the development of life expectancy. Over the last 100 years, life expectancy in Germany has more than doubled, with men having a life expectancy of 77.7 years and women of 82.8 years. ${ }^{4}$ In 2060 these life expectancies will be even higher, with men living 86.7 years and women living 90.4 years on average. ${ }^{5}$ This increase in life expectancy has an imminent effect on the German Pension system, since the average duration of receiving a pension increases and thus pensions have to be paid for longer.

The third factor of demographic change that has to be mentioned is immigration. For the future population number and age structure, net migration is decisive, which is the difference between immigration and emigration. As a country with economic and social attractiveness, Germany has a very high net migration within the European Union and also worldwide. In 2015, net migration in Germany reached the highest level in German history with a value of approximately 1.14 million. ${ }^{6}$ The main factor of this high number is the inflow of asylum seekers from war and crisis regions in Africa and Asia, especially from Syria, and it is not expected in the future that net migration will reach such high numbers every year. From 2021 to 2060, the German Federal Office of Statistics estimates net migration to be at 200,000 people per year. Nevertheless, this predicted positive net migration alone cannot solve the problems connected with the shrinking and aging of the German population.

Since this demographic change has been in full swing for decades, the German pension system is already under significant pressure. The German pension system is funded by a pay-as-you-go system, which means that the working population from today is paying into a system from which today's pensioners, and hence the working population from yesterday, will receive their current pension benefits. This system only works if today's working population can trust that when they retire, tomorrow's working population will pay the necessary contributions to finance their pensions. Everyone in this system becomes once contributor and pensioner, which establishes a basic consensus in the context of social justice. ${ }^{7}$ The individual benefits that every individual household receives are in close equivalence with the insurance premiums that are paid during the working lives. In Germany, the so-called participation equivalency principle ("Teilhabeäquivalenzprinzip") is applied. This principle provides that households of the same birth year should be treated equally in terms of their payments of contribution and their insurance

${ }^{4}$ Ibidem, p. 34.

5 Ibidem, p. 36.

6 Statistisches Bundesamt, Statistisches Jahrbuch. Deutschland und Internationales, Wiesbaden 2017, p. 52.

${ }^{7}$ H. Benölken, N. Bröhl, Altersvorsorge am Scheideweg, Wiesbaden 2018, p. 7. 
benefits. ${ }^{8}$ The idea behind such insurance models is to enable insured persons to maintain their standard of living when they are entering their retirement phase.

The pension system in Germany can be described as a three-pillar system, with statutory pensions from the pension system, corporate and private pensions. For a long time, pension plans beyond the benefits of statutory pension insurance were not necessary to achieve the goal of maintaining the standard of living. However, given the above described negative consequences that demographic change brings, the pay-as-you-go system is exposed to problems, as far fewer contributors in the future will have to finance the benefits of a growing number of beneficiaries. The development of the old-age dependency ratio describes this problem quite well. While in 1980, for every 100 persons of working age, only 27 persons were of retirement age, there were already 35 persons of retirement age in 2015, which demonstrates an increase of about 44 percent. ${ }^{9}$ The prognosis worsens by looking into the year 2060, where there could already be 65 persons of retirement age for every 100 persons of working age. Because it is mandatory for most people, statutory pension insurance is the largest German social security branch, with 54.4 million insured persons, 21 million pensioners and with pension expenditures of 268.9 billion $€$ in $2017 .{ }^{10}$ Benefits from statutory pension insurance still account for the largest share of income of pensioners. These benefits make up on average 63 percent of the pensioners' households. ${ }^{11}$ To prevent old-age poverty, a coordination between the various pension systems is therefore necessary.

With more than 20 million beneficiaries, the company pension scheme is not only the oldest, but also still the most important pension scheme after statutory pension insurance. ${ }^{12}$ The private pension scheme includes all private asset accumulation, which aims at gaining income in old age. These can be insurance products, investments in the capital market or real estate. Among the insurance products, the most popular product is the so-called "Riester pension", with 16.5 million Riester savers by the third quarter of $2017 .{ }^{13}$ In order to make the company pension scheme and the private pension scheme more attractive, the legislator decided to promote these forms of old-age provision, by granting several tax benefits and perks.

Overall, the state has made some efforts to enable a large part of the population to access the company pension scheme or to care about an additional private pension scheme, but still too few people care about the decline in the benefits of statutory pension insurance and thus the danger of old-age poverty. For this reason, doubts arise as to whether classical public policy techniques such as tax incentives

8 O. Ehrentraut, Alterung und Altersvorsorge: das deutsche Drei-Säulen-System der Alterssicherung vor dem Hintergrund des demografischen Wandels, Berlin 2006, p. 25.

9 Statistisches Bundesamt, Statistisches Jahrbuch..., p. 55.

${ }^{10}$ Deutsche Rentenversicherung, Jahresbericht 2017, Berlin 2017, p. 2.

11 BMAS, Rentenversicherungsbericht 2017, Berlin 2017, p. 22.

${ }^{12}$ H. Benölken, N. Bröhl, op. cit., p. 7.

13 Ibidem, p. 117. 
or statutory regulation are still sufficient to achieve the desired outcome. In order to cope with this problem, it would be very helpful to have a look at the insights of behavioral economics on how to deal with this situation.

\section{Insights of behavioral economics}

The model of the Homo Oeconomicus - or the economic man — is the basis for nearly every model of neoclassical economics. According to this theory, each of us acts self-interested, completely rational, and utility maximizing, and we are assumed to have constant preferences and full information about all the alternatives we can choose from. If this assumption applied to everybody, then the problem of not caring about additional pension schemes to maintain the standard of living when entering the retirement phase would not be present. Everybody would be aware of the demographic changes and the fact that people are living longer and having fewer children. In this case everybody would care about additional company and private pension plans to ensure that they have enough money for old age. This also includes that everybody can determine how much to save and how to invest this amount of money properly. From this conception of man, an economic policy has derived that is based on the wrong assumptions of people's behavior and postulates for each individual a scope for decision-making that is as large as possible.

However, with the increased use of experiments in the field of behavioral economics, it became clear that the assumptions of the neoclassical model of Homo Oeconomicus are empirically untenable. Laboratory experiments in behavioral economics challenge these above-mentioned assumptions of the omnipresent Homo Oeconomicus in economics, because the majority of experiment participants does not behave according to the assumptions of this standard model. People are often wrong, they are easy to influence and often make objectively wrong decisions. Moreover, people decide on the basis of vague rules of thumb, overestimate their abilities, become inert from loss aversion, depend on the status quo and often lack self-control. In addition, it could be shown that people have social preferences, which means that they not only consider their own outcome when making decisions, but also the outcome of others. Social preferences include reciprocity, fairness, altruism, inequality aversion and envy. To put it in a nutshell, economic decisions are influenced by psychological factors.

Knowing about these psychological factors, behavioral economists suggest a fundamental different economic policy. The aim is to motivate as many people as possible to take care of an additional pension plan in addition to statutory pension insurance or to motivate those who already have an additional pension plan to invest more money. Very often people have additional pension plans but they do not invest enough money, even though it would be financially possible for 
them. A policy concept that is very helpful in achieving this aim comes from the behavioral economist Richard $\mathrm{H}$. Thaler and the professor of jurisprudence Cass R. Sunstein. They reject - like classic liberal economists - a direct dictation of the individual by the state, but they argue in favor of a gentle pressure, with which the state helps people to find the right direction, but at the same time leaves them the option to change their minds if they want to. They gave this policy concept the name "nudge". ${ }^{14}$ To be considered a nudge, such interventions by the state must not set specific incentives. Consequently, subsidies, taxes or penalties do not count as nudges. Also, such interventions may not be associated with monetary costs for the persons concerned. The broader term for their new movement is libertarian paternalism - two terms that initially sound contradictory. However, libertarian paternalism is about helping people to make better decisions than they would make on their own, but without using any form of coercion. Thaler and Sunstein are aware of the fact that humans are not always able to make the best decisions for themselves, but it does not take much to support them. Sometimes only a few nudges can help. A crucial factor that significantly influences people's actions is the power of inertia, which should not be underestimated. For several reasons, people are not willing to change their current situation. This behavior is also known as the status quo bias. ${ }^{15}$ It describes the phenomenon that people prefer things to stay the same by doing nothing, even if the decisions to make are of great importance and only small transition costs are involved. Only if the negative effects are sufficiently felt and a desire for change exists, people will effectively want to change something in the dynamics of their current situation. But this inertia and sticking to the status quo can be harnessed by using nudges.

A central point in the structuring of the decision process is so-called choice architecture, which is designed by a so-called choice architect. Thaler and Sunstein describe the architect as someone responsible for organizing the environment in which people make decisions. ${ }^{16}$ In conclusion, the choice architect influences the addressee through the architecture of the given option. The contextualization of choices has a significant impact on the decision-making process of an individual. However, crucial to this contextualization, remains that no option will be eliminated. The ultimate freedom of choice of the individual must therefore not be limited in the concept of Thaler and Sunstein. To ensure the freedom of choice, nudges must be used as gently as possible and it has to be possible that they can be bypassed without great effort. The prerequisite for this is clear and transparent communication.

14 R.H. Thaler, C.R. Sunstein, Nudge: Improving decisions about health, wealth and happiness, New York 2009, p. 6.

15 W. Samuelson, R. Zeckhauser, "Status quo bias in decision making”, Journal of Risk and Uncertainty 1, 1988, no. 1, p. 8.

16 R.H. Thaler, C.R. Sunstein, op. cit., p. 14. 
The most obvious nudges are default options that determine what happens when people do not act but do nothing. Behavioral economists know that people are naturally comfortable and have a limited attention span. Moreover, additional effort is often omitted or forgotten. A targeted structuring of default options makes use of people's inertia. In general, a default option is accepted because choosing an alternative option requires to be active and people will very often choose the path of least resistance. In most cases, the decision context is reshaped in such a way that the desired behavior is also the most pleasant and easiest for the decision makers. This approach can thus be denoted paternalistic, because it patronizes individuals. At the same time this paternalism can be described as libertarian, because it gives the individual at any time the opportunity to decide against the path she or he is nudged. Setting default options can be very useful for making people participate in corporate pension plans. Thaler and Sunstein called this approach automatic enrollment. ${ }^{17}$ The automatic participation in a pension plan is one of the most well-known and at the same time most important nudges in old-age provision. Automatic enrollment is about pension plans that are automatically deposited unless people consciously decide to not participate in such pension plans. This is called opting-out. In the area of corporate pensions such an approach means that in contrast to a compulsion to save, such as a statutory obligation with a binding contribution, a standard pension plan is automatically offered when signing an employment agreement. Of course, employees do not have to accept this standard pension plan. They can choose an alternative option and it is even possible for them to not participate in any corporate pension plan at all. But if employees do not change this default option, they automatically pay into the offered pension plan. The combination of automatism with the possibility to refuse the offer thus represents only a gentle intervention but no compulsion.

Empirical research documents a tremendous influence of such automatisms. In the USA, in the context of old-age provision, company contribution plans (401k) are the prime example. The automatic investment of a part of the income by the employer has contributed to a massive increase in old-age provision. The possibility of opting out in such cases is rarely used by the employees. ${ }^{18}$ In general, it should be a no-brainer for all employees to take part in such corporate pension plans, because as already mentioned above they are often connected with several tax benefits and perks and thus with free money. Despite this fact, enrollment rates in Germany for a company pension plan are far away from $100 \%$. With the introduction of the so-called Occupational Pensions Strengthening Law ("Betriebsrentenstärkungsgesetz") in 2018 automatic enrollment in company pension

17 Ibidem, p. 118.

18 J. Beshears et al., "The importance of default options for retirement saving outcomes: Evidence from the United States", [in:] Social security policy in a changing environment, Chicago 2009, p. 171. 
plans is now allowed in Germany. According to this law, employee's earnings up to a certain limit ( $4 \%$ of the contribution assessment ceiling of the statutory pension insurance scheme, i.e., $254 €$ per month in 2017) can be used to accumulate an occupational pension fund. Since the share of companies that make use of this law is too small, strong effects cannot be seen yet.

In contrast to the traditional incentive form of tax benefits, changing the default option can have an enormous impact. This is not only based on people's status quo bias, but also on the suspensory behavior described above. Even those employees who want to deselect and get out of the system tend to delay this decision because it is often associated with unattractive bureaucratic activity. Above all, this has a positive effect on the pension plans for young employees, as they very often tend to postpone decisions about their pension plans to the future, or in the worst case do not care.

The only little problem that default saving plans have is that they usually have low savings rates that are below the allowed limit. Although automatic enrollment is quite effective, many employees continue to save at this low rate which leads to the situation that for many of them the accumulated money for retirement is not sufficient to maintain a standard of living. This is because the average citizen can hardly calculate her potential pension gap, which means that this gap is overestimated or underestimated to a considerable extent. In addition, the average decision maker does not have enough willpower to adhere to a plan for as long as a persistent pension plan requires. Also, impatience plays an important role here as well, because the real result of old-age provision that is going on for decades is very far away and difficult to quantify.

The question now is how to help people who save too little. Companies can help here and help their employees overcome internal resistance to saving. For such cases, Richard Thaler and Shlomo Benartzi developed a program they called 'Save More Tomorrow', which serves to convince employees indirectly to invest more into their retirement plans. ${ }^{19}$ Save More Tomorrow is about having employees agree in advance that a part of each pay rise they get will automatically go into the pension plan. This can also be designed as an opt-out solution in which employees must consciously decide against the support. The procedure is that at the beginning a calculation should clarify the amount one wants to cover for old age regularly. This decision has no immediate effect. Subsequently, the savings plan comes into force, as soon as the employee agrees to invest a small part into the pension plan in parallel with the next pay rise. This approach does not hurt very much as the person concerned still notices an increase in their salary account, while at the same time more money goes into the pension plan. Furthermore, the person concerned agrees to increase the contribution rates for each pay rise until

19 R.H. Thaler, S. Benartzi, "Save More Tomorrow ${ }^{\mathrm{TM}}$ : Using behavioral economics to increase employee saving", Journal of Political Economy 112, 2004, no. S1, p. 164. 
a previously agreed maximum level has been reached. There is always the possibility to leave the program in order to make it more pleasant for employees. But then already the tendency of the people to the status quo works in their favor. The status quo bias makes leaving the program rather unlikely, as many experiments show. Thus, the inertia of people is used to increase savings instead of preventing savings. According to Thaler and Sunstein, combining the Save More Tomorrow program with automatic enrollment, can achieve both increased savings rates and high participation rates. ${ }^{20}$ This is also the most effective way to increase enrollments in Save More Tomorrow plans.

\section{Conclusion}

To summarize this, it is not very easy to make people aware of the fact that due to the ongoing demographic change it is not enough to simply rely on the statutory pension scheme. Building also on the other two pillars, company pension plans and private pension plans, has become crucial to preserve the standard of living when reaching retirement. Thus, investing the right amount of money into these additional pension plans is something every employee has to care about.

The insights of behavioral economists mentioned in this essay - especially automatic enrollment and the Save More Tomorrow program — are very useful tools to help people with their savings plans, as many empirical studies show. With the introduction of the Occupational Pensions Strengthening Law, the German government has made a big step towards opening the policy to nudges. Many countries like the USA, the United Kingdom, New Zealand, and Australia have already had positive experiences with implementing these tools and the acceptance of these programs among citizens is indeed high. The question remains whether the results of such programs would be valid for Germany. Despite a fundamentally different organization of the pension system compared to the USA or the UK, the answer is yes, since the patterns of behavior that these programs make use of are universal and can also be demonstrated in experiments in Germany. Because of this, it would be very reasonable if those insights of behavioral economists will influence economic policy more in the future and also how companies deal with this situation.

\section{References}

Benölken H., Bröhl N., Altersvorsorge am Scheideweg, Wiesbaden 2018.

Beshears J. et al., "The importance of default options for retirement saving outcomes: Evidence from the United States", [in:] Social security policy in a changing environment, Chicago 2009, pp. 167-195.

20 R.H. Thaler, C.R. Sunstein, op. cit., p. 125. 
BMAS (Bundesministerium für Arbeit und Soziales), Rentenversicherungsbericht 2017, Berlin 2017.

Deutsche Rentenversicherung, Jahresbericht 2017, Berlin 2017.

Ehrentraut O., Alterung und Altersvorsorge: das deutsche Drei-Säulen-System der Alterssicherung vor dem Hintergrund des demografischen Wandels, Berlin 2006.

Haub C., Dynamik der Weltbevölkerung 2002, Stuttgart 2002.

Samuelson W., Zeckhauser R., "Status quo bias in decision making", Journal of Risk and Uncertainty 1, 1988, no. 1, pp. 7-59.

Statistisches Bundesamt, Bevölkerung Deutschlands bis 2060. 13. koordinierte Bevölkerungsvorausberechnung, Wiesbaden 2015.

Statistisches Bundesamt,. Statistisches Jahrbuch Deutschland und Internationales, Wiesbaden 2017.

Thaler R.H., Benartzi S., "Save more tomorrow ${ }^{\mathrm{TM}}$ : Using behavioral economics to increase employee saving", Journal of Political Economy 112, 2004, no. S1, pp. 164-187.

Thaler R.H., Sunstein C.R., Nudge: Improving decisions about health, wealth, and happiness, New York 2009. 